\title{
RESEARCH PAPER \\ Effects of contracts and work relationships on salaries and income distribution of workers in the Chilean agricultural sector, 1996 and 2006
}

\author{
Jorge Campos ${ }^{1}$ and William Foster ${ }^{2}$ \\ ${ }^{1}$ Departamento de Política Agraria, Oficina de Estudios y Políticas Agrarias, Odepa, Ministerio de \\ Agricultura, Gobierno de Chile, Teatinos 40, Piso 8, Santiago, Chile. \\ ${ }^{2}$ Departamento de Economía Agraria, Facultad de Agronomía e Ingeniería Forestal, Pontificia Universidad \\ Católica de Chile. Av. Vicuña Mackenna 4860, Macul, Santiago, Chile.
}

\begin{abstract}
J. Campos and W. Foster. 2012. Effects of contracts and work relationships on salaries and income distribution of workers in the Chilean agriculture sector, 1996 and 2006. Cien. Inv. Agr. 39(1): 5-17. During the past thirty years the Chilean economy generally and agriculture specifically have grown considerably, raising both per capita GDP and observed real wages of salaried workers. There has been, however, a concern about the country's persistent unequal distribution of income. Among the possible factors associated with income inequality is the relatively infrequent use of contracts in seasonal and occasional work, both strongly present in agriculture. Based on Chilean household surveys (CASEN) for 1996 and 2006, impacts of contracts and work relationships (permanent, seasonal, etc.) on salaries, and their possible contributions to inequality, were measured, accounting for schooling, ethnicity, work experience, geographic zones, and other variables correlated with salaries. Separate hourly-wage equations for men and women were estimated. Ceteris paribus, employees with contracts earn more than those without, and those in a permanent work relationship earn more than those seasonally employed. The negative effects of not having a contract and being in a non-permanent work relationship are greater for women. Schooling is the single most important factor in explaining unequal salaries; however, the contribution of schooling to salary improvement has not changed considerably over time. Contracts and work relationship are important in explaining salary inequality, especially in the case of women.
\end{abstract}

Key words: Agriculture, labor, gender, income distribution, inequality, work contract, work relationship.

\section{Introduction}

Over the last 30 years Chile has experienced economic growth, political stability and increasing integration into world markets. Per capita GDP has doubled, poverty rates have decreased. Chile's unequal distribution of income is noteworthy, and

Received May 27, 2010. Accepted December 29, 2011. Corresponding author: jacampo1@uc.cl measured levels of inequality have remained empirically stable over time (Solimano and Torche, 2008, Contreras et al., 2001, Valdés, 1999). Of the many factors that might contribute to income inequality, various characteristics of labor markets have been hypothesized, notably the informality of contracts and the fluidity and impermanency of work relations. The period 1990-2006 was characterized by a rapidly evolving labor market in response to changing patterns of production among sectors 
competing for workers of different skill levels. In the case of agriculture, as the composition of production continued shifting from traditional to export-oriented crops, work relationships other than "permanent" (mainly seasonal) increased over time (Amuedo-Dorantes, 2005). As elsewhere, agriculture behaves differently than the rest of the Chilean economy, due to its link with biological cycles and products associated with highly seasonal activities. About $60 \%$ of Chilean rural households that depend on agriculture earn the bulk of their incomes from salaried work (the remainder are smaller-farm self-employed or larger-farm employers). Salaried-work households in agriculture show higher poverty rates than the self-employed and those in urban areas (Valdés and Foster, 2009). The participation of these workers in total agricultural earned income in the sector increased from $37 \%$ to $52 \%$ in the period under review, and it has been the only group that increased in number, rising 21.5\% between 1990 and 2006 (Valdés et al., 2008).

As seen in Table 1, the number of female agricultural employees increased between 1996 and 2006 by $65 \%$, while men recorded a $6.3 \%$ rise. The male/female ratio is a simple indicator of the composition of employees from a gender perspective; it's decrease reflects that the development of agricultural activities, particularly the growth of the agro-export model, which has led to an increase in labor demand satisfied by a greater supply of women entering the labor market (Table 1) (1996 and 2006 surveys CASEN, MIDEPLAN, 1996 and 2006, respectively).

This present study focuses on salaried workers, particularly on their wages and the degree of inequality that characterizes the distribution of hourly earnings of these employees. The objectives of this research are two-fold: a) to determine the impact of the existence of different contracts and working relationships on hourly earnings of employees in the agricultural sector, controlling for characteristics such as education, ethnicity, work experience, and others; and b) to determine the contribution of these variables to the dispersion of the distribution of hourly wages and the resulting income inequality shown over time. The analysis also emphasizes differences associated with gender.

Table 1. Chilean salaried workers in the Economy and Agriculture Sector in Chile: 1996-2006 (Age 16-65).

\begin{tabular}{lccc}
\hline Economy & 1996 & 2006 & $\begin{array}{c}\text { Growth Rate } \\
1996 / 2006\end{array}$ \\
\hline Men & $2,463,136$ & $2,906,083$ & $17 \%$ \\
Women & $1,406,534$ & $1,909,727$ & $36 \%$ \\
M/W Ratio & 1.8 & 1.5 & \\
Agriculture & & & \\
Men & 423,133 & 450,198 & $6.3 \%$ \\
Women & 82,068 & 135,499 & $65 \%$ \\
M/W Ratio & 5.2 & 3.3 & \\
\hline
\end{tabular}

Source: Own from CASEN 1996 and 2006.

\section{Materials and methods}

This research uses the National Socioeconomic Characterization Survey (CASEN), of Ministerio de Planificación de Chile (MIDEPLAN) for the years between 1996 and 2006, available from the institution's website (http://www.mideplan.cl/casen). For purposes of this investigation, an employee is defined as an individual between 16 and 65 years old who claims to be engaged in a relationship of subordination or dependence with an employer; an agriculture worker is employed in a business, industry or service which is active in the agriculture sector of the economy (Ministry of Planning, 2006).

Income determination and the correction equation for selection bias

The analysis focuses on participants in the labor market; observations are drawn from a selfselecting subset of the population between 16 and 65 . The methodology used to correct the selection bias corresponds to the two-stage method of Heckman (1979). The income of employees is analyzed using a standard semi-log (log-lin) re- 
gression (Mincer, 1974). The econometric method allowed quantifying the marginal effect or impact of a contract (or lack of it) on income levels, as well as identifying how work relationships affect salaries. In addition, several variables have been added to characterize sub-groups of employees. Summary statistics are shown in Table 2.

Selection-bias correction was performed after the application of a standard probit model of the probability of observing a person working or employed. The sample from the CASEN survey corresponds to the individuals belonging to the active labor force in agriculture, both employed and unemployed, in the age range 16-65. The objective is to obtain an indicator that would show the marginal propensity of individuals to be observed as a salaried employee. This indicator is included in the earnings equations and is known as the Inverse Mills Ratio (IMR). Observed and selected individuals correspond to a dichotomous variable, $T_{i}$, that equals 1 when the $\mathrm{i}$-th individual declares to be an employee with an hourly wage. In any other case, $T_{i}=0$. The probability of being employed is a function of observed characteristics:

$$
P\left(T_{i}=1 \mid W_{i}\right)=\Phi\left(W_{i \gamma}\right)
$$

where $W_{i}$ is a vector of observed characteristics of individuals and $\mathrm{Y}$ is a vector of coefficients common across individuals in a given year. The $\operatorname{IMR}\left(\lambda_{\mathrm{it}}\right)$ is calculated as:

$\lambda_{i t}=\frac{\hat{\phi}_{i t}\left(\alpha_{i t} z / \Psi_{i t}\right)}{\widehat{\Phi}_{i t}\left(\alpha_{i t} z / \Psi_{i t}\right)}$

where: $\hat{\phi}_{i t}$ corresponds to the estimated function of density probability, and $\hat{\phi}_{i t}$ corresponds to the estimated function of cumulative distribution for each group of employees tested. The functional form to determine the impact of this and all other selected variables on salary are as follows:

$$
\ln Y_{i t}=\varphi\left(, \mathrm{e}_{i t}, \mathrm{e}_{\mathrm{it}}^{2} \exp _{i t}, V_{i t}, \lambda_{\mathrm{it}}\right)+\varepsilon_{t}
$$

where: $i=[1, n], n$ is the number of individuals observed (salaried employees) and $t=1996$ and 2006. Y represents the income per hour, e schooling (in years, which enters quadratically to account for possible diminishing returns), exp indicates the work experience (in years). $\mathrm{V}$ is a vector that contains the other explanatory variables: the existence of an employment contract, specific work relationship (see below), marital status, ethnicity, occupation, region, urban-to-rural surface area in the worker's municipality (as an indicator of rurality), number of workers in the firm employing the person, and the indicator of selection bias, $\lambda_{\mathrm{it}}$ IRM explained above. Schooling is defined in this way considering the nonlinearity of the effect on income. All other variables are dichotomous. The income used is the logarithm of hourly earnings expressed in Chilean pesos of November 2008, using the average annual CPI as a deflator.

\section{Decomposition of inequality of labor income}

With respect to labor income inequality, the main question is how to use the information contained in the income equations to identify the contributions of each of the explanatory variables to the dispersion of income.

The methodology detailed below is based on Shorrocks (1982). Fields and Yoo (2000) and Amuedo-Dorantes (2005) are interesting applications of this method. To summarize, the decomposition of wage income inequality separates the contribution of the $j$-th explanatory variable, $Z$, relative to the total variance in a given year. The share, $s_{j}$, of the total (estimated) population variance of wages can be rewritten in terms of the sample correlation coefficient between (log) hourly wage and the explanatory variable, scaled by the regression coefficient, $a_{j}$ :

$\mathrm{s}_{\mathrm{j}}(\ln Y)=\operatorname{cov}\left[a_{j} Z_{j}, \ln Y\right] / \sigma^{2}(\ln Y)=\frac{a_{j} * \sigma\left(Z_{j}\right) * \operatorname{cor}\left[Z_{j}, \ln Y\right]}{\sigma(\ln Y)}$

where $\sum_{j} s j(\ln Y)=100 \%$ 
Table 2. Statistical summary of variables used, for salaried workers in agriculture sector in Chile: 1996-2006 (Age 16-65).

\begin{tabular}{|c|c|c|c|c|c|c|c|c|}
\hline \multirow[b]{3}{*}{ Variable } & \multicolumn{4}{|c|}{ Men } & \multicolumn{4}{|c|}{ Women } \\
\hline & \multicolumn{2}{|c|}{1996} & \multicolumn{2}{|c|}{2006} & \multicolumn{2}{|c|}{1996} & \multicolumn{2}{|c|}{2006} \\
\hline & Mean & $\begin{array}{c}\text { Stand. } \\
\text { Dev. }\end{array}$ & Mean & $\begin{array}{c}\text { Stand. } \\
\text { Dev. }\end{array}$ & Mean & $\begin{array}{c}\text { Stand. } \\
\text { Dev. }\end{array}$ & Mean & $\begin{array}{c}\text { Stand. } \\
\text { Dev. }\end{array}$ \\
\hline With Work Contract & 0.584 & 0.493 & 0.710 & 0.454 & 0.587 & 0.492 & 0.743 & 0.437 \\
\hline No Work Contract & 0.383 & 0.486 & 0.272 & 0.445 & 0.376 & 0.484 & 0.243 & 0.429 \\
\hline No info about Contract & 0.033 & 0.180 & 0.013 & 0.114 & 0.036 & 0.187 & 0.009 & 0.093 \\
\hline Permanent & 0.564 & 0.496 & 0.520 & 0.500 & 0.240 & 0.427 & 0.248 & 0.432 \\
\hline Specific Task & 0.039 & 0.195 & 0.056 & 0.230 & 0.027 & 0.163 & 0.038 & 0.190 \\
\hline Fixed Term & 0.021 & 0.144 & 0.020 & 0.139 & 0.035 & 0.184 & 0.016 & 0.127 \\
\hline Seasonal & 0.373 & 0.483 & 0.399 & 0.490 & 0.694 & 0.461 & 0.690 & 0.463 \\
\hline Other Work Relation & 0.000 & 0.020 & 0.004 & 0.065 & 0.000 & 0.007 & 0.004 & 0.065 \\
\hline Married & 0.529 & 0.499 & 0.458 & 0.498 & 0.342 & 0.474 & 0.343 & 0.475 \\
\hline Years of Schooling & 7.028 & 3.783 & 8.013 & 3.705 & 7.889 & 3.552 & 9.138 & 3.523 \\
\hline Ethnicity & 0.061 & 0.239 & 0.078 & 0.268 & 0.020 & 0.141 & 0.055 & 0.228 \\
\hline $\operatorname{Exp}<5$ & 0.066 & 0.248 & 0.082 & 0.275 & 0.103 & 0.304 & 0.126 & 0.332 \\
\hline Exp 5-10 & 0.146 & 0.353 & 0.110 & 0.313 & 0.183 & 0.386 & 0.143 & 0.350 \\
\hline Exp 11-15 & 0.139 & 0.346 & 0.097 & 0.296 & 0.165 & 0.371 & 0.111 & 0.314 \\
\hline $\operatorname{Exp}>16$ & 0.649 & 0.477 & 0.711 & 0.454 & 0.549 & 0.498 & 0.620 & 0.485 \\
\hline Service-related workers & 0.009 & 0.094 & 0.008 & 0.088 & 0.028 & 0.164 & 0.008 & 0.090 \\
\hline Managers \& Directors & 0.012 & 0.107 & 0.002 & 0.040 & 0.008 & 0.089 & 0.001 & 0.029 \\
\hline Professional & 0.017 & 0.128 & 0.016 & 0.124 & 0.008 & 0.088 & 0.013 & 0.112 \\
\hline Technicians & 0.023 & 0.148 & 0.010 & 0.101 & 0.030 & 0.171 & 0.023 & 0.150 \\
\hline Office workers & 0.010 & 0.098 & 0.011 & 0.104 & 0.043 & 0.204 & 0.044 & 0.204 \\
\hline Agricultural workers & 0.213 & 0.409 & 0.240 & 0.427 & 0.161 & 0.367 & 0.145 & 0.352 \\
\hline Manufacturing workers & 0.020 & 0.141 & 0.035 & 0.183 & 0.009 & 0.097 & 0.053 & 0.224 \\
\hline Operatives & 0.079 & 0.270 & 0.074 & 0.262 & 0.005 & 0.069 & 0.025 & 0.157 \\
\hline Low-skill occupations & 0.618 & 0.486 & 0.604 & 0.489 & 0.708 & 0.455 & 0.688 & 0.463 \\
\hline Region Metropolitana & 0.141 & 0.348 & 0.129 & 0.336 & 0.257 & 0.437 & 0.176 & 0.381 \\
\hline I Region & 0.009 & 0.096 & 0.010 & 0.099 & 0.011 & 0.106 & 0.008 & 0.092 \\
\hline II Region & 0.003 & 0.051 & 0.002 & 0.048 & 0.000 & 0.010 & 0.001 & 0.024 \\
\hline III Region & 0.016 & 0.125 & 0.017 & 0.128 & 0.023 & 0.151 & 0.030 & 0.171 \\
\hline IV Region & 0.057 & 0.232 & 0.062 & 0.242 & 0.076 & 0.264 & 0.085 & 0.279 \\
\hline V Region & 0.101 & 0.301 & 0.106 & 0.307 & 0.151 & 0.358 & 0.147 & 0.354 \\
\hline VI Region & 0.131 & 0.337 & 0.152 & 0.359 & 0.160 & 0.366 & 0.190 & 0.393 \\
\hline VII Region & 0.158 & 0.365 & 0.169 & 0.375 & 0.207 & 0.405 & 0.183 & 0.386 \\
\hline VIII Region & 0.178 & 0.383 & 0.145 & 0.352 & 0.053 & 0.224 & 0.068 & 0.252 \\
\hline
\end{tabular}




\begin{tabular}{|c|c|c|c|c|c|c|c|c|}
\hline \multirow[b]{3}{*}{ Variable } & \multicolumn{4}{|c|}{ Men } & \multicolumn{4}{|c|}{ Women } \\
\hline & \multicolumn{2}{|c|}{1996} & \multicolumn{2}{|c|}{2006} & \multicolumn{2}{|c|}{1996} & \multicolumn{2}{|c|}{2006} \\
\hline & Mean & $\begin{array}{c}\text { Stand. } \\
\text { Dev. }\end{array}$ & Mean & $\begin{array}{c}\text { Stand. } \\
\text { Dev. }\end{array}$ & Mean & $\begin{array}{c}\text { Stand. } \\
\text { Dev. }\end{array}$ & Mean & $\begin{array}{c}\text { Stand. } \\
\text { Dev. }\end{array}$ \\
\hline IX Region & 0.071 & 0.256 & 0.077 & 0.267 & 0.016 & 0.127 & 0.043 & 0.202 \\
\hline X Region & 0.115 & 0.319 & 0.117 & 0.321 & 0.036 & 0.186 & 0.064 & 0.244 \\
\hline XI Region & 0.011 & 0.104 & 0.007 & 0.084 & 0.005 & 0.070 & 0.003 & 0.057 \\
\hline XII Region & 0.010 & 0.098 & 0.005 & 0.073 & 0.005 & 0.073 & 0.002 & 0.039 \\
\hline Small Firm & 0.423 & 0.494 & 0.272 & 0.445 & 0.174 & 0.379 & 0.120 & 0.325 \\
\hline Medium Firm & 0.324 & 0.468 & 0.260 & 0.439 & 0.413 & 0.492 & 0.299 & 0.458 \\
\hline Large Firm & 0.202 & 0.401 & 0.351 & 0.477 & 0.397 & 0.489 & 0.507 & 0.500 \\
\hline Rural Zone & 0.583 & 0.493 & 0.515 & 0.500 & 0.382 & 0.486 & 0.394 & 0.489 \\
\hline Urban Zone & 0.417 & 0.493 & 0.485 & 0.500 & 0.618 & 0.486 & 0.606 & 0.489 \\
\hline Mill's ratio & 0.495 & 0.239 & 0.387 & 0.217 & 0.282 & 0.251 & 0.231 & 0.237 \\
\hline $\mathrm{N}^{\circ}$ Obs. Expansion Factors & \multicolumn{2}{|c|}{423,133} & \multicolumn{2}{|c|}{450,198} & \multicolumn{2}{|c|}{82,068} & \multicolumn{2}{|c|}{135,499} \\
\hline $\mathrm{N}^{\circ}$ Obs. No Expansion Factors & \multicolumn{2}{|c|}{5,083} & \multicolumn{2}{|c|}{15,966} & \multicolumn{2}{|c|}{1,083} & \multicolumn{2}{|c|}{4,086} \\
\hline
\end{tabular}

All variables are dummies with years of schooling like exception. In the case of dummies variables, the average indicates the proportion in the respective population of the characteristic represented by the variable.

Note that the residual error's contribution to inequality is interpreted as the share of the dependent variable's variance left unexplained by the model proposed.

\section{Changes in income inequality}

Fields and Yoo (2000) show how to evaluate the change over time in the contribution of the $\mathrm{j}$-th explanatory variable to income inequality of any arbitrary inequality index. For purposes of this study, the Gini index and the variance of log hourly earnings were used to measure inequality. Changes in the inequality index are evaluated using the years 1996 and 2006. The total change from a given inequality measure is the sum of weighted changes of the index:

In summary, the detailed breakdown of the inequality in equation (4) allows one to quantify the contribution to hourly wage variance between 1996 and 2006 of contracts and different work relationships. Given the change in income inequality, equation (6) is used to measure how much of the change in inequality across workers' wages between 1996 and 2006 is attributable to chages in the number workers with contracts as well as to with the various work relationships.

$$
I(.)_{2006}-I(.)_{1996}=\sum_{j}\left[s_{j, 2006} * I(.)_{2006}-s_{j, 1996} * I(.)_{1996}\right]
$$

and, $\quad \prod_{j}(I())=.\sum_{j}\left(\left[s_{j, 2006} * I(.)_{2006}-s_{j, 1996} * I(.)_{1996}\right] /\left[I(.)_{2006}-I(.)_{1996}\right]\right)$

where, $\sum_{j} \Pi_{j}(\mathrm{I}())=.100 \%$ 


\section{Descriptive analysis}

Contracts and work relationships, 1996 and 2006. Table 3 presents the percentages of employees "with contract" and "with no contract" in agriculture, differentiated by gender and observed in the years under study. In the year 1996 both genders had about $58 \%$ of employees with contract, while in the year 2006, women reached a level of contract employment greater than their male counterparts: $70 \%$ versus $67 \%$.

Table 3. Incidence of Contracts among male and female employees in Chilean agriculture: 1990-2006. (Age 16-65).

\begin{tabular}{lcc}
\hline & \multicolumn{2}{c}{ Year } \\
\cline { 2 - 3 } Employee & 1996 & 2006 \\
\hline Men & 58.35 & 67.89 \\
With Work Contract & 38.30 & 27.24 \\
No Work Contract & 3.35 & 4.87 \\
No information Women & 58.72 & 70.83 \\
With Work Contract & 37.64 & 24.29 \\
No Work Contract & 3.64 & 4.88 \\
No information &
\end{tabular}

Source: Own from CASEN 1996 and 2006.

With respect to work relationships in agriculture, Table 4 shows the percentages of each, differentiated by sex. Men in a "Permanent" working relationship represented 56\% of employees in 1996, declinng to almost $52 \%$ in 2006 . In women, these levels were almost half of that observed in men, with levels close to $24 \%$ in 1996 and almost $25 \%$ in 2006. In contrast, women reached close to $70 \%$ for "seasonal" relationships, while men did not exceed $40 \%$. Gender differentiation is observed within same working relationship, as the case of "seasonal", where men are outnumbered by about 30 percentage points by women. One explanation for higher levels of female seasonal workers is related to their high participation in seasonal activities related to fruit. Table 5 shows a greater concentration of women in regions dominated by fruit growing, that is, between regions IV and VII of the country.
Table 4. Incidence of different types of work relations among male and female employees working in the Chilean agriculture: 1996-2006 (Age 16-65).

\begin{tabular}{lcc}
\hline & \multicolumn{2}{c}{ Year } \\
\cline { 2 - 3 } Work Relation & 1996 & 2006 \\
\hline Men & 56.4 & 51.98 \\
Permanent & 37.24 & 39.86 \\
Seasonal & 2.12 & 2.39 \\
Fixed-term & 3.94 & 5.6 \\
Specific Tasks & 0.3 & 0.17 \\
Others relations & & \\
Women & 23.7 & 24.84 \\
Permanent & 69.72 & 68.99 \\
Seasonal & 3.5 & 2.07 \\
Fixed-term & 2.74 & 3.77 \\
Specific Tasks & 0.34 & 0.33 \\
Others relations &
\end{tabular}

Source: Own from CASEN 1996 and 2006.

The dominance of the "Permanent" relationship in men, approximately 30 percentage points more than women, may be due to the activities of this sex in agriculture, many of which would require their permanent presence during the year. For example, work management and maintenance of farm infrastructure, care and management of livestock, among others are found primarily in the south of the country, between regions VIII and $\mathrm{X}$, where extensive farming predominates (Table 5).

Work relationships (Permanent, Specific Task, Fixed Term, Seasonal, or Other) have much to do with the seasonality of production and related activities. A sustainable agricultural enterprise requires ways to mobilize a workforce of variable size at critical times and tasks, and in some cases to employ at least a base level of permanent workers (Collins and Krippner, 1999). The use of permanent workers in agricultural activities has been studied in the literature from around the world, including aspects such as lower-cost supervision (Hart, 1986) due to the existence of tasks that require judgement, discretion and care, 
Table 5. Employees in the Chilean agriculture in 2006, by Region (Age 16-65).

\begin{tabular}{lccc}
\hline Region & Men & Women & $\begin{array}{c}\text { Ratio } \\
\text { M/W }\end{array}$ \\
\hline I & 4,499 & 1,145 & 3.9 \\
II & 1,059 & 80 & 13.2 \\
III & 7,554 & 4,098 & 1.8 \\
IV & 28,005 & 11,545 & 2.4 \\
V & 47,563 & 19,962 & 2.3 \\
VI & 68,547 & 25,783 & 2.6 \\
VII & 76,303 & 24,753 & 3.1 \\
VIII & 65,340 & 9,246 & 7.0 \\
IX & 34,747 & 5,759 & 6.0 \\
X & 52,682 & 8,642 & 6.0 \\
XI & 3,177 & 444 & 7.1 \\
XII & 2,445 & 207 & 11.8 \\
Metro & 58,277 & 23,835 & 2.4 \\
\hline Total Chile & 450,198 & 135,499 & 3.3 \\
\hline
\end{tabular}

Source: Own from CASEN 2006.

which often are difficult to monitor (Eswaran and Kotwal, 1985).

Income inequality in 1996 and 2006. Table 6 presents the levels of income inequality measured using the Gini index and the log variance index for hourly earnings of employees in 1996 and 2006. Between these ten years, inequality declined in similar magnitude for both genders.

\section{Results}

Marginal effects of contracts and work relationships

Table 7 shows the values of variable estimators used in the equations of income, for men and women.The absence of an employment contract has a negative

Table 6. Measures of real hourly earnings inequality among male and female employees in Chilean agriculture: 1996-2006 (Age 16-65).

\begin{tabular}{lccccc}
\hline & \multicolumn{2}{c}{ Men } & & \multicolumn{2}{c}{ Women } \\
\cline { 2 - 3 } \cline { 5 - 6 } Inequality Indices & 1996 & 2006 & & 1996 & 2006 \\
\hline Gini coefficient & 0.3915 & 0.2648 & & 0.3863 & 0.2356 \\
$\begin{array}{l}\text { Log variance of } \\
\text { real hourly earnings }\end{array}$ & 0.5537 & 0.3453 & & 0.4887 & 0.3261 \\
\hline
\end{tabular}

Source: Own from CASEN 1996 and 2006. impact on wages only for men in 1996, while in 2006, it is negative for both sexes, but the effect is greater for women. The negative impact on wage of no contract reached levels of $21.9 \%$ for males, and about $27 \%$ for females. Table 8 shows these marginal effects expressed in monetary amounts and the average monthly salary received according to the factors used in this study. Having no contract compared to having a contract in 2006, would result in a decrease in the average monthly salary of $\$ 31,000$ and $\$ 33,000$ (Chilean pesos) in men and women, respectively, economically significant effects considering that the average monthly agricultural wages for 2006 are $\$ 142,000$ and $\$ 123,000$ for men and women with contracts.

Turning to work relationships, the "temporary" condition, in the case of men, is associated with a reduced income of about $11 \%$ in 1996 and $9 \%$ in 2006. Table 8 shows that the reduced amount that a temporary employee received, ceteris paribus, was approximately $\$ 30,000$ and $\$ 20,000$ in 1996 and 2006, respectively. Note that the average monthly wage observed for those with a "permanent" relationship is $\$ 252,000$ and $\$ 200,000$ in 1996 and 2006.

There are also negative impacts for women with a "seasonal" compared to a "permanent" relationship, although this effect decreased from 17.6\% lower wage in 1996 to $3.9 \%$ in 2006 (Table 7). This is important because this seasonal agricultural labor group is where women are disproportionately represented (Table 4). The lower impact for the year 1996 as compared to men is possibly due to the type of seasonal labor performed by women. Higher levels of productivity for women in seasonal work would reduce the negative effects of this relationship compared to that permanent employment.

\section{Contributions to inequality}

Table 9 shows the contribution of each explanatory variable to wage inequality in each year under study and in both sexes. In the case of men, the 
Table 7. Estimated coefficients from male and female earnings regressions. Dependent variable: Logarithm of hourly earnings.

\begin{tabular}{|c|c|c|c|c|c|c|c|c|}
\hline \multirow{3}{*}{$\begin{array}{l}\text { Variables } \\
\text { No work contract }\end{array}$} & \multicolumn{4}{|c|}{ Men } & \multicolumn{4}{|c|}{ Women } \\
\hline & \multicolumn{2}{|c|}{1996} & \multicolumn{2}{|l|}{2006} & \multicolumn{2}{|l|}{1996} & \multicolumn{2}{|l|}{2006} \\
\hline & -0.112 & $*$ & -0.219 & $*$ & 0.008 & & -0.274 & $*$ \\
\hline No information about contract & -0.205 & $*$ & -0.029 & $*$ & -0.086 & $*$ & -0.104 & $*$ \\
\hline Specific Task & 0.097 & $*$ & -0.049 & $*$ & -0.367 & $*$ & -0.069 & $*$ \\
\hline Fixed-Term & -0.089 & $*$ & -0.077 & $*$ & 0.276 & $*$ & -0.021 & $*$ \\
\hline Seasonal & -0.115 & $*$ & -0.092 & $*$ & -0.176 & $*$ & -0.039 & $*$ \\
\hline Other work relations & -0.407 & * & -0.030 & $*$ & 0.196 & $*$ & 0.122 & $*$ \\
\hline Married & 0.041 & $*$ & 0.048 & $*$ & -0.005 & & 0.020 & $*$ \\
\hline Years of schooling & -0.023 & $*$ & -0.027 & $*$ & 0.014 & $*$ & -0.010 & $*$ \\
\hline Years of schooling ${ }^{2}$ & 0.003 & $*$ & 0.004 & $*$ & 0.000 & & 0.002 & \\
\hline Ethnicity & -0.024 & * & -0.039 & $*$ & 0.106 & $*$ & 0.052 & $*$ \\
\hline Five to 10 years of experience & 0.098 & $*$ & 0.068 & $*$ & 0.124 & $*$ & 0.078 & $*$ \\
\hline 11 to 15 years of experience & 0.106 & $*$ & 0.154 & $*$ & 0.227 & $*$ & 0.008 & $* *$ \\
\hline $16+$ years of experience & 0.146 & $*$ & 0.222 & $*$ & 0.172 & $*$ & 0.088 & $*$ \\
\hline Managers and Directors & 0.713 & * & 0.735 & $*$ & 0.181 & $*$ & 0.297 & $*$ \\
\hline Professionals & 1.464 & $*$ & 1.072 & $*$ & 1.193 & $*$ & 1.206 & $*$ \\
\hline Technicians & 0.878 & $*$ & 0.610 & $*$ & 0.488 & $*$ & 0.864 & $*$ \\
\hline Office workers & 0.512 & $*$ & 0.211 & $*$ & 0.376 & $*$ & 0.419 & $*$ \\
\hline Agriculture workers & -0.042 & * & 0.125 & $*$ & -0.358 & $*$ & -0.002 & \\
\hline Manufacturing workers & 0.374 & $*$ & 0.125 & $*$ & -0.765 & $*$ & 0.040 & $*$ \\
\hline Operatives & 0.019 & $*$ & 0.166 & $*$ & 0.103 & & 0.080 & $*$ \\
\hline Low-skill occupations & -0.099 & $*$ & 0.009 & $* * *$ & -0.256 & $*$ & -0.094 & $*$ \\
\hline I Region & 0.205 & $*$ & -0.273 & $*$ & 0.002 & & -0.073 & $*$ \\
\hline II Region & 0.228 & $*$ & 0.252 & $*$ & -0.490 & $*$ & 0.004 & \\
\hline III Region & 0.021 & & -0.038 & $*$ & -0.066 & $*$ & 0.135 & $*$ \\
\hline IV Region & -0.148 & $*$ & -0.141 & $*$ & -0.049 & $*$ & 0.042 & $*$ \\
\hline V Region & -0.041 & $*$ & -0.085 & $*$ & -0.051 & $*$ & 0.082 & $*$ \\
\hline VI Region & -0.051 & $*$ & -0.102 & $*$ & 0.071 & $*$ & 0.052 & $*$ \\
\hline VII Region & -0.187 & $*$ & -0.130 & $*$ & -0.215 & $*$ & -0.033 & $*$ \\
\hline VIII Region & -0.183 & $*$ & -0.199 & $*$ & -0.224 & $*$ & -0.064 & $*$ \\
\hline IX Region & -0.205 & $*$ & -0.179 & $*$ & -0.444 & $*$ & -0.215 & $*$ \\
\hline X Region & -0.061 & $*$ & -0.060 & $*$ & 0.138 & $*$ & 0.035 & $*$ \\
\hline XI Region & 0.069 & $*$ & 0.065 & $*$ & 0.100 & $*$ & 0.132 & $*$ \\
\hline XII Region & 0.129 & * & -0.062 & $*$ & -0.008 & & 0.062 & $*$ \\
\hline Medium Firm & 0.057 & * & 0.047 & * & 0.019 & $*$ & 0.060 & $*$ \\
\hline Large Firm & 0.136 & * & 0.104 & * & 0.061 & $*$ & 0.055 & $*$ \\
\hline Urban & 0.091 & * & 0.031 & $*$ & 0.077 & $*$ & -0.026 & $*$ \\
\hline Inversa Mill's Ratio & -0.139 & $*$ & -0.008 & & 0.062 & $*$ & 0.014 & \\
\hline Cons & 5.996 & $*$ & 6.059 & $*$ & 5.979 & $*$ & 6.052 & $*$ \\
\hline $\mathrm{R}^{2}$ & 0.3525 & & 0.3575 & & 0.2554 & & 0.3329 & \\
\hline Observations & 403,335 & & 431,320 & & 76,308 & & 123,424 & \\
\hline
\end{tabular}

Source: Own from CASEN 1996 and 2006.

Permanent work relation, no married, no ethnicity, less than five years of potential work experience, servicerelated occupations, XIII Region, small firms and rural zones are used as reference categories. *denotes statistical significance at the $1 \%$ level, **indicates statistical significance at the $5 \%$ level, and ***represents statistical significance at the $10 \%$ level. 
most important variable in both years is schooling. In women, schooling is important only in 2006. In 2006 the contributions to inequality of not having a contract are $4.9 \%$ and $5.2 \%$ for men and women, respectively. In 1996, the contribution is much less, $1.5 \%$ for men, and zero for women. There is a notable change in the importance of contracts for women between 1996 and 2006: from a negligible impact, the effect of having no contract is the second most important following schooling. The impact of "no contract" represents a one-sixth of the total contribution explained by the variables included (5.2 percentage points out of an $\mathrm{R}^{2}$ of $33 \%$ ).

Work relationships, except for "seasonal", do not contribute to wage inequality. But the relationship "seasonal" in the case of men did contribute to aproximately $1.6 \%$ of the inequality measure. For women, however, the contribution of "seasonal" fell from a relatively high contribution of 3.1\% in 1996 to $0.7 \%$ in 2006 . The observed decrease of the contribution of "seasonal" in the case of women correlates with the growth in the importance of seasonal work among women. As a characteristic of workers becomes more widespread its relative contribution to observed income differences in any one year declines, although in terms of comparisons between years there is a more equal distribution of income.

The contributions of contracts and work relationships to changes in earnings inequality in Chilean agriculture: 1996 and 2006

This section turns to the contributions of contract

Table 8. Average monthly earning's effects of contract and work relations in the Chilean agriculture (Chilean Pesos of November 2008). Work contract and permanent work relation are reference categories.

\begin{tabular}{lcc}
\hline Men & 1996 & 2006 \\
\hline No work contract (Compared to having contract) & $-19,139$ & $-31,333$ \\
Specific Task (Compared to having a permanent work relation) & 23,256 & $-10,235$ \\
Fixed Term (Compared to having a permanent work relation) & $-23,762$ & $-17,058$ \\
Seasonal (Compared to having a permanent work relation) & $-30,081$ & $-20,670$ \\
Other relation (Compared to having a permanent work relation) & $-96,058$ & $-9,432$ \\
Average Monthly Earnings With Work Contract & 173,987 & 142,424 \\
Average Monthly Earnings of Permanent Work Relation & 252,783 & 200,677 \\
Women & & \\
No work contract (Compared to having contract) & 0 & $-33,316$ \\
Specific Task (Compared to having a permanent work relation) & $-62,123$ & $-12,761$ \\
Fixed Term (Compared to having a permanent work relation)) & 47,098 & $-4,712$ \\
Seasonal (Compared to having a permanent work relation) & $-29,880$ & $-8,442$ \\
Other relation (Compared to having a permanent work relation) & 35,788 & 23,755 \\
Average Monthly Earnings With Work Contract & 158,525 & 123,391 \\
Average Monthly Earnings of Permanent Work Relation & 168,812 &
\end{tabular}

Source: Own from regressions coefficients estimates.

Notes: The CPI index was obtained from Banco Central de Chile (http://www.bcentral.cl). In terms of equivalence of foreign currency in November 2008, the average value of a dollar (US \$) fell to $\$ 651$ Chilean pesos (CLP \$). 
Table 9. The marginal contribution of characteristics to earnings inequality and to the change in inequality measures: 1996-2006 (Age 16-65).

\begin{tabular}{|c|c|c|c|c|c|c|c|c|}
\hline \multirow[b]{3}{*}{ Variables } & \multicolumn{4}{|c|}{ Factor inequality weight of each variable } & \multicolumn{4}{|c|}{$\begin{array}{c}\text { Contribution of each variable to the CHANGE } \\
\text { in inequality as measured by: }\end{array}$} \\
\hline & \multicolumn{2}{|c|}{ Men } & \multicolumn{2}{|c|}{ Women } & \multicolumn{2}{|c|}{ Men } & \multicolumn{2}{|c|}{ Women } \\
\hline & 1996 & 2006 & 1996 & 2006 & Gini & $\begin{array}{l}\log \\
\text { Variance }\end{array}$ & Giini & $\begin{array}{l}\log \\
\text { Variance }\end{array}$ \\
\hline No work contract & 0.0157 & 0.0496 & -0.0009 & 0.0527 & -0.0551 & -0.0405 & -0.0849 & -0.1086 \\
\hline No information about contract & 0.0035 & 0.0001 & 0.0007 & 0.0005 & 0.0106 & 0.0091 & 0.0011 & 0.0012 \\
\hline Specific Task & 0.0001 & 0.0017 & 0.0065 & 0.0013 & -0.0033 & -0.0026 & 0.0146 & 0.0169 \\
\hline Fixed-Term & 0.0000 & 0.0003 & 0.0092 & -0.0002 & -0.0007 & -0.0006 & 0.0240 & 0.0281 \\
\hline Seasonal & 0.0160 & 0.0174 & 0.0312 & 0.0077 & 0.0131 & 0.0137 & 0.0680 & 0.0785 \\
\hline Other work relations & 0.0000 & 0.0000 & 0.0000 & 0.0002 & 0.0000 & 0.0000 & -0.0002 & -0.0002 \\
\hline Married & 0.0029 & 0.0048 & 0.0001 & 0.0006 & -0.0010 & -0.0002 & -0.0005 & -0.0007 \\
\hline Schooling & -0.0403 & -0.0581 & 0.0176 & -0.0202 & -0.0031 & -0.0108 & 0.0765 & 0.0932 \\
\hline Schooling $^{2}$ & 0.1134 & 0.1761 & -0.0003 & 0.0826 & -0.0177 & 0.0094 & -0.1300 & -0.1667 \\
\hline Ethnicity & 0.0006 & 0.0010 & 0.0006 & 0.0003 & -0.0002 & 0.0000 & 0.0011 & 0.0012 \\
\hline Five to 10 years of experience & 0.0009 & 0.0000 & 0.0008 & 0.0014 & 0.0027 & 0.0023 & -0.0001 & -0.0003 \\
\hline 11 to 15 years of experience & 0.0019 & 0.0029 & 0.0076 & 0.0002 & -0.0001 & 0.0003 & 0.0191 & 0.0224 \\
\hline $16+$ years of experience & -0.0040 & 0.0001 & -0.0078 & -0.0056 & -0.0128 & -0.0110 & -0.0111 & -0.0121 \\
\hline Managers and Directors & 0.0165 & 0.0052 & 0.0019 & 0.0005 & 0.0400 & 0.0351 & 0.0039 & 0.0045 \\
\hline Professionals & 0.0936 & 0.0860 & 0.0342 & 0.0729 & 0.1095 & 0.1062 & -0.0262 & -0.0434 \\
\hline Technicians & 0.0447 & 0.0176 & 0.0260 & 0.0652 & 0.1014 & 0.0897 & -0.0353 & -0.0526 \\
\hline Office workers & 0.0070 & 0.0027 & 0.0263 & 0.0340 & 0.0159 & 0.0140 & 0.0143 & 0.0109 \\
\hline Agriculture worker & 0.0003 & 0.0061 & 0.0114 & 0.0000 & -0.0119 & -0.0094 & 0.0293 & 0.0343 \\
\hline Manufacturing worker & 0.0071 & 0.0018 & 0.0061 & 0.0006 & 0.0182 & 0.0159 & 0.0147 & 0.0171 \\
\hline Operatives & 0.0003 & 0.0066 & 0.0005 & 0.0010 & -0.0129 & -0.0102 & -0.0004 & -0.0007 \\
\hline Low-skill occupation & 0.0178 & -0.0022 & 0.0349 & 0.0244 & 0.0597 & 0.0510 & 0.0513 & 0.0559 \\
\hline I Region & 0.0040 & 0.0083 & 0.0000 & 0.0010 & -0.0049 & -0.0031 & -0.0016 & -0.0020 \\
\hline II Region & 0.0192 & 0.0412 & -0.0052 & 0.0003 & -0.0269 & -0.0174 & -0.0138 & -0.0162 \\
\hline III Region & 0.0002 & 0.0001 & -0.0007 & -0.0002 & 0.0004 & 0.0003 & -0.0015 & -0.0018 \\
\hline IV Region & -0.0004 & -0.0004 & 0.0000 & 0.0000 & -0.0003 & -0.0003 & 0.0000 & 0.0000 \\
\hline V Region & -0.0003 & -0.0007 & -0.0001 & 0.0017 & 0.0006 & 0.0004 & -0.0031 & -0.0039 \\
\hline VI Region & 0.0006 & 0.0011 & -0.0006 & -0.0006 & -0.0002 & -0.0001 & -0.0006 & -0.0006 \\
\hline VII Region & -0.0026 & -0.0008 & -0.0008 & -0.0003 & -0.0063 & -0.0055 & -0.0015 & -0.0017 \\
\hline VIII Region & -0.0007 & 0.0018 & -0.0033 & -0.0001 & -0.0061 & -0.0050 & -0.0082 & -0.0096 \\
\hline IX Region & 0.0121 & 0.0082 & 0.0520 & 0.0135 & 0.0205 & 0.0187 & 0.1123 & 0.1293 \\
\hline X Region & -0.0003 & 0.0017 & -0.0018 & -0.0002 & -0.0045 & -0.0037 & -0.0042 & -0.0049 \\
\hline XI Region & -0.0025 & -0.0018 & -0.0006 & -0.0018 & -0.0039 & -0.0036 & 0.0012 & 0.0017 \\
\hline XII Region & 0.0004 & -0.0015 & -0.0004 & 0.0028 & 0.0045 & 0.0037 & -0.0054 & -0.0068 \\
\hline Medium Firm & 0.0001 & 0.0002 & 0.0001 & 0.0002 & 0.0000 & 0.0000 & -0.0001 & -0.0002 \\
\hline Large Firm & 0.0019 & 0.0001 & 0.0001 & 0.0000 & 0.0057 & 0.0050 & 0.0002 & 0.0003 \\
\hline Urban & 0.0145 & 0.0042 & 0.0090 & -0.0018 & 0.0359 & 0.0315 & 0.0259 & 0.0306 \\
\hline Mill's Ratio & 0.0049 & 0.0000 & 0.0002 & 0.0003 & 0.0153 & 0.0132 & 0.0001 & 0.0001 \\
\hline Residual (1-R²) & 0.6475 & 0.6425 & 0.7446 & 0.6671 & 0.6579 & 0.6558 & 0.8658 & 0.9001 \\
\hline Sum & 1 & 1 & 1 & 1 & 1 & 1 & 1 & 1 \\
\hline
\end{tabular}

Source: Own from CASEN 1996 and 2006. 
(or lack thereof) and work relationships to changes in the two measures of earnings inequality between 1996 and 2006. The Gini index and the log variance of hourly wages both yield similar results. To facilitate the discussion here, the Gini results are used. First note that the contributions to changes presented in Table 9 are contributions to reductions in total income inequality, as seen in Table 6. The contribution of "no contract" to the fall in the inequality indices is negative in the case of both sexes (using the Gini index, for men $-5 \%$ and for women $-8 \%$ ). The change in the distribution of employment contracts across workers between 1996 and 2006 (Table 3) contributed, ceteris paribus, to increasing wage inequality. The "seasonal" condition contributed to the reduction of inequality, with $1.3 \%$ for men and $6.8 \%$ for women. These contributions to changes in the inequality index should be considered in the light of the total explained changes to the indices. The joint contribution of the explanatory variables included in the analysis to the reduction in the Gini index of inequality is $35 \%$ for men and $14 \%$ for women. Therefore, in the case of females the contribution to the decline in wage inequality due to the growth in the rate of contracts accounts for $57 \%$ of the total explained decline.

\section{Discussion}

The wage equations allow an assessment of the marginal impacts of the variables "no contract" and work relationships on the hourly earnings of agricultural employees in Chile for 1996 and 2006. The regression analysis corrected for possible selection bias due to censoring of the sample. The regression coefficients permit estimating the contributions of the explanatory variables to inequality indices in each year and to changes in the indices between 1996 and 2006. For both genders the impact on wages and inequality measures of having no contract is negative. Notably the impacts of the work relationship indicators depend on gender, demonstrating the usefulness of differentiating the analysis by men and women.
Not having a contract is notably negatively correlated with women's wages.

This study provides empirical evidence to complement previous descriptive works on Chilean agricultural employees, including primarily seasonally-employed females,(e.g., Fernandez, 2007). The amounts of forgone monthly income due to informality or non-existence of a contract are economically significant, especially in the case of workers at the lower end of the income distribution. Although not specifically addressed in this study, the results suggest a link between contract status and the type of work relationship and the poverty status of a worker. It is true that the incidence of poverty fell during the period 1996 and 2006, when the proportion of workers under contract increased. The evidence of this study is suggestive, but further research would aid in understanding the possible interrelationship between poverty, work formality, and seasonal work.

Employees who work on a permanent basis enjoy higher wages than those working seasonally or occasionally. For men the negative impact on wages of having a non-permanent work relationship was observed for both 1996 and 2006; interestingly, for women, however, the negative impact of a seasonal work on wages was reduced. Future research would be required to explain in detail the type and nature of activities done by employees of both genders, with an emphasis on how women might have benefited more than men over time when it comes to relationships other than "permanent". Possibly this effect is due the link between the intermittent labor supply and the seasonality of demand by agricultural producers. A variable supply of female labor (for tempoary, short-term work) in sync with seasonal, demand for labor for harvest and sorting reduces the marginal effects of seasonal work on wage, possibly due to the demand curve shifting out at the same time that higher-marginal-product female workers are returning to the labor market during summer months. 
Regarding the distribution of income across workers of different characteristics, contracts and work relationships contribute significantly to inequality in agriculture. Notably, in the case of women workers in the agricultural sector in 2006, the distribution of the "no-contract" characteristic contributed to wage inequality to a degree slightly lower than the contribution of schooling. Fernández (2007) notes the growing demand for contracts by female seasonal workers, suggesting that these employees associate contracts with higher wages.

With regard to the observed changes in measures of inequality between 1996 and 2006 for both sexes, changes in the distribution of contracts across the work force helps explain the reduction in wage inequality, especially for women. With respect to work relationships other than permanent, changes to the distribution of the characteristic "seasonal" work also contributed to reducing the inequality indices, especially in women. Thus, this type of work relationship, associated with a greater flexibility in labor management, applies to individuals of similar marginal products, and whose incomes, therefore, are also similar.
The result show that the lack of an employment contract, at least during in the years analyzed, is negatively correlated with the wages of employees. With respect to work relationships, "permanent" workers receive higher salaries than seasonal or temporary. This last result is particularly relevant for agriculture, and even more so for women workers in the type of activities that predominate in Chile. The research shows that the changes in the distribution of contracts and work relationships contributed to the reduction in inequality measures. It is important to note that in agriculture the ability to explain the wage variation across workers appears low, as shown by the $\mathrm{R}^{2}$ coefficients. But among the explanatory variables the distribution of schooling remains the main contributor to wage inequality across workers, and changes to this distribution has led to a reduction in inequality from 1996 to 2006.

\section{Acknowledgements}

The views expressed in this article are the sole responsibility of their authors and do not necessarily represent the institutions where the work took place.

\section{Resumen}

\section{J. Campos y W. Foster. 2012. Efectos del contrato y relación de trabajo sobre el salario} y distribución del ingreso en la agricultura de Chile en los años 1990 y 2006. Cien. Inv. Agr. 39(1): 5-17. Durante los últimos treinta años la economía chilena se ha transformado. El crecimiento económico ha sido destacado, aumentando el PIB per cápita y los salarios reales. Por supuesto, la actividad agrícola no ha estado ajena a ello. Sin embargo, existe preocupación sobre la alta desigualdad del ingreso en Chile y su aparente persistencia. La informalidad asociada a la falta de un contrato de trabajo y la proliferación de relaciones de trabajo estacionales u ocasionales, podrían ser señalados como posibles causas que expliquen los niveles de desigualdad, más aún en la Agricultura, donde la informalidad laboral es relevante. A partir de la información contenida en la Encuesta de Caracterización Socioeconómica (CASEN) de los años 1996 y 2006, se establecen los impactos marginales de los contratos y relaciones de trabajo sobre el salario y sus respectivas contribuciones a la desigualdad, controlándose factores como escolaridad, etnia, experiencia laboral, zona geográfica, etc. Se establece que, ceteris paribus, los individuos que tienen un contrato de trabajo obtienen ingresos superiores que sus contrapartes que no los poseen, así también, aquellos con una relación de trabajo permanente, respecto de relaciones temporales o por obra. Los impactos negativos son superiores en las 
mujeres. La principal contribución a la desigualdad la realiza la escolaridad, aunque a través del tiempo esta variable no ha mejorado el ingreso de los asalariados. Los contratos y relaciones de trabajo son importantes en la explicación de la desigualdad, siendo más relevante en el caso de las mujeres, donde la falta de un contrato de trabajo no contribuyó a reducir la desigualdad, más bien, amplía las brechas salariales.

Palabras clave: Contratos, relaciones de trabajo, asalariados, agricultura, género, desigualdad, distribución del ingreso.

\section{References}

Amuedo-Dorantes, C. 2005. Work contracts and earnings inequality: The case of Chile. Journal of Development Studies 41(4):589-616.

Collins, J., and G. Krippner. 1999. Permanent labor contracts in Agriculture: Flexibility and subordination in a new export crop. Comparative Studies in Society and History 41:510-534.

Contreras, D., O. Larrañaga, J. Litchfield, and A. Valdés. 2001. Poverty and income distribution in Chile 1987-1998. New Evidence. Cuadernos de Economía 38(114).

Eswaran, M., and A. Kotwal. 1985. Theory of Contractual Structure in Agriculture. American Economic Review 75:352-367.

Fernández, S. 2007. ¡Las uvas de la ira! Geografía, género y agroindustria en Chile. Revista Universitaria de Geografía 2007(16):179-199.

Fields, G., and G. Yoo. 2000. Falling Labor Income Inequality in Korea's Economic Growth: Patterns and Underlying Causes. Review of Income and Wealth 46:139-159.

Hart, G. 1986. Interlocking Transactions: Obstacles, Precursors or Instruments of Agrarian Capitalism. Journal of Development Economics 23:177203.

Heckman, J. 1979. Sample Selection Bias as a Specification Error. Econometrica 47:153-161.
MIDEPLAN. 2006. Documento Metodológico CASEN 2006, Encuesta de Caracterización Socioeconómica. Ministerio de Planificación (MIDEPLAN), Gobierno de Chile.

Mincer, J. 1974. Schooling, experience and earnings. National Bureau of Economic Research, NBER and Columbia Univ. Press, New York. p. $145-$ 152.

Shorrocks, A.F. 1982. Inequality Decomposition by Factor Components. Econométrica 50:193-211.

Solimano, A., and A. Torche. 2008. La distribución del ingreso en Chile 1987-2006: Análisis y consideraciones de política. Documentos de Trabajo №480. Banco Central de Chile, Santiago, Chile.

Valdés, A. 1999. Pobreza y distribución del ingreso en una economía de alto crecimiento, Chile 1987-1995. Estudios Públicos 75: 5-47. Centro de Estudios Públicos, Santiago, Chile.

Valdés, A., and W. Foster. 2009. Características estructurales de los hogares agrícolas chilenos: Una tipología de los hogares rurales y determinantes de ingreso en base a la Encuesta Casen 2003. Estudios Públicos 113: 109-150. Centro de Estudios Públicos, Santiago, Chile.

Valdés, A., W. Foster, R. Pérez, and R. Rivera. 2008. Evolución del ingreso agrícola real en América Latina, 1990-2005: Evidencia en base a Cuentas Nacionales y Encuestas de Hogares. Revista Española de Estudios Agrosociales y Pesqueros 218:71-98. 
